\title{
Promotional Strategy Preferences and Buying Decisions of Western Appliances Customers
}

\author{
Rony S. Toling
}

\begin{abstract}
This study assessed the promotional strategy preferences and buying decisions of the Western Appliances customers in Metro Manila, Philippines. Through a validated self-made survey questionnaire, the data were gathered from 100 purposively chosen customers of Western Appliances. The percentage, arithmetic mean, standard deviation, Pearson correlation analysis, t- test, and regression analysis were applied using data management statistics tool. The results revealed that there were statistically significant correlations between the promotional strategies and customer buying decisions variables. In particular, promotional strategies implemented by the subject firm have significantly high positive correlations with all the respondent's preference variables such as sales promotion, advertising, personal selling, direct marketing and public relations. There was also statistically significant correlations between the promotional strategies and the customer buying decisions variables. Therefore, increase or decrease in effectiveness of promotional strategies' implementation significantly results in an increase or decrease in the purchase decisions of customers in Western Appliances in Metro Manila.
\end{abstract}

Keywords:

buying decisions, customer preference, promotional strategies, purchase decisions, marketing tool, consumer behavior

Suggested Citation: Toling, R.S. (2021). Promotional Strategy Preferences and Buying Decisions of Western Appliances Customers. International Journal of Academe and Industry Research, Volume 2, Issue 2, pp. 1- 24.

\footnotetext{
About the author:

An MBA and Ph.D. (on-going) holder and a professor in the College of Business Administration at Cainta Catholic College.
} 


\section{Introduction}

The retail industry of the Philippines is characterized by large market base for consumers with high disposable income. The industry maintains its momentum driven by rapid growth of the country's population, social developments, and the nation's economic growth and development. Key factors attributed to retail industry growth are changing consumer needs, population growth, increasing youth segment, rising purchasing power of the people, and consumer confidence. The retail industry is projected to rise over the long term.

The market of the retail industry is demographically diverse. Consumers prefer cheap goods but convenience stores primarily dominate the industry with high product demand. The industry benefits from the economy's sustained growth and high private consumption. Although the majority of the people has low income due to less agricultural production, the changing demographics offers new trends that eventually encouraged the formulation of new strategies and business opportunities to fit the changes in the consumer behavior.

One of the major key player in the country's retail industry is the Western Appliances. It offers a wide range of kitchen and home appliances, electronics, and entertainment systems. It has maintained its existence for more than fifty years offering major brands of product assortments and providing customer satisfaction through the provision of high quality products and the commitment to create value to customers. Recognized as one of the top retailers for appliances in Metro Manila, the firm seeks to develop a competitive marketing tool to continuously cater to the changing needs of the market and to better serve them through effective communication tools that are of preference to their needs.

This study aimed to determine the perception of the customers on the promotional strategies of Western Appliances vis a vis buying decisions of customers based on sales promotion, advertising, personal selling, direct marketing and public relations. It also tested the significant relationship between the preferences of the customers on the promotional strategies and customers' buying decisions. This study provides a promotional strategy framework that benefits retail business in targeting potential market niche. It provides validation on the promotional strategies that are appropriate for a particular target. 


\section{Literature Review}

\subsection{Theoretical Background}

This study is anchored on the "Factors that Influence Selection of Promotional Mix' as postulated by Tanner and Raymond (2010).

\section{Figure 1}

\section{Factors the Influence Selection of Promotional Mix}

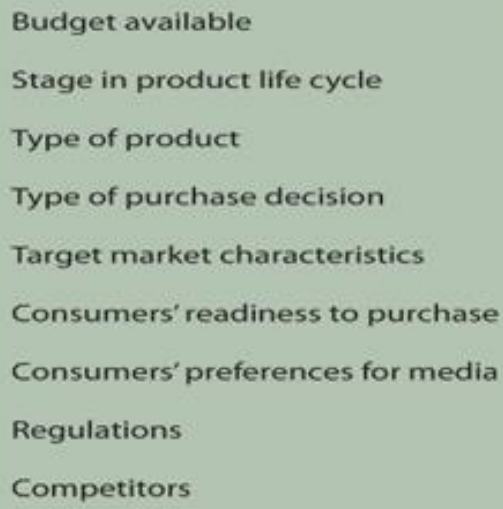

Advertising

Personal setting

Sales promotion

Public relations

Direct marketing
Print

Television

Radio

Online

Social

News release

Mail

As presented in Figure 1, marketers select varied types of media based on their perceptions. The framework shows a number of factors that influence the choice of elements that comprise the promotional mix. For example, the budget available affects the number of individuals that a promotion can reach and the frequency of people exposure. Firms may not get the exposure required to be successful if budget is not sufficient. Moreover, product life cycle stage also influence the amount and type of promotion used. Consumer awareness and trial are needed in purchase decisions of consumers and businesses. Products that are in the introductory stages will require a lot of funds in the creation of awareness in the marketplace. Building awareness entails more communication in the beginning of the product life cycle. In addition, product type and purchase decisions need varied types of promotion. High 
involvement products require professional selling to build customer understanding on the product features and how the product operates.

\subsection{Related Studies}

There are several studies conducted on the promotional strategies and consumer behavior. For example, the study conducted by MarketingSherpa (2016) through an online survey fielded with a sample of United States consumers showed that companies need to focus on the ways customers want to receive promotions and regular updates. It was also revealed that there was strong preference of consumers to receive updates in the email which was less popular with marketers. Customers also prefer visiting websites which is less popular also among marketers instead marketers prefer attending local events with less consumers' preference.

There are strong evidence showing mismatch between the company strategies and customers' preferences. The marketers' practices to offer customers to engage with brands lag behind top choices of consumers to receive promotions and updates. There is more preference of consumers to receive print updates in the email than the tendency of marketers to offer. They also prefer to visit firm's website for promotions and updates without being contacted, while marketers prefer to use the method of laissez-faire for customer engagement. According to Ahmad (2015), the primary benefit of promotions is consumers' stimulation in comparing brands and the ability to evaluate possibilities for purchase decisions. In his study, the firms in Pakistani industries use varied promotional strategies based on preferences of consumers to boost company sales. It was evident that attitude towards price discounts, coupons, free samples, and buy one get one free are significantly related to buyer behavior.

In another study by Familmaleki et al. (2015), the effects of sales promotion on the decision making process of buyers was investigated. The increased profits and customer purchases were found to come from marketing activities related to sales promotions. The strategy was proven to be a vital marketing tool specifically in reaching targeted consumers and persuading them to buy. The strategy is used primarily to elicit an impact directly from customers' purchase behavior. Buying behavior is also influenced directly by sales promotion. The various elements of sales promotion such as price discounts, free samples, 
physical and social surroundings motivate buying behavior. Results of the study revealed significant relationships between price cutting, customer value, customer satisfaction, behavioral intentions, and value. It was also showed that attractive sales promotions enhance repurchases intentions of customers.

A similar study of Shamout (2016) determined the impact of sales promotion in the retail industry that involved price discount, coupons, sample, buy one get one free on the buying behavior of consumers. Findings of the study revealed that promotional tools positively induce consumer's behavior but coupons were found to have no influence on the buying behavior of customers. Sales promotion was intended to add extra product and service value within the framework of strategic marketing. It increased purchases and was found to be more effective when used when the deal is going on. This is congruent to the study of Anyadighibe et al. (2014) on the impact of personal selling in retail banks on productivity. It was found also that customer retention, sales volume, and customer relationship have statistically significant relationships.

In another aspect of marketing, public relations is an essential part of the marketing mix for brands of consumer products in establishing a level of trust and educating customers on new products and services (Dennis Rutzou Public Relations, 2017). The public relations programs, when considered as part of marketing strategy, can perform effectively as a communication tool.

\section{Methodology}

This study used the descriptive method of research. Under this method, descriptions were generated from responses that were gathered from the survey dealing with promotional strategy preferences of customers of Western Appliances in Metro Manila. This method enabled the gathering of opinions and comments from the respondents. The method is designed to gather all information regarding the present situation relative to the subject under investigation. It describes the nature as it exists at the time of the study specifically focusing on the promotional strategy preference and buying decisions of customers (Keiss, 1996; Calderon \& Gonzales, 1993). 
The respondents were selected through purposive sampling, a selective and judgement sampling technique wherein own judgment was used to choose the members of sample. According to Black (2010), representative sample can be obtained by means of a sound judgement, which can provide time and cost savings. Through personal observation at the Western Appliances Branch located in Commonwealth Quezon City in the Philippines, a total of 100 customers were chosen to participate in the survey. There were fifty (50) female and fifty (50) male customers who consented to answer the survey questionnaire.

The main research instrument was a self-constructed survey questionnaire validated by academic and industry experts. A pilot testing was also conducted to test the questionnaire validity and reliability. The survey questionnaire consisted of statements related to the promotional strategy preference and the buying decisions of customers answerable by a range of scale from 5 as "strongly agree" to 1 as "strongly disagree." An unstructured interview was conducted at random respondents to elicit more information. The consent, safety and confidentiality of the respondents and their answers were assured.

The data gathered were treated with various statistical treatments such as arithmetic mean, standard deviation, Pearson correlation analysis and t-test.

\section{Findings and Discussion}

\section{Table 1}

Customers’ Perception on Sales Promotion Strategies

\begin{tabular}{lcccc}
\hline \multicolumn{1}{c}{ Sales Promotion Indicators } & M & S.D. & V.I. \\
\hline $\begin{array}{l}\text { Sales promotion tools on samples, shopping cards \& coupons build brand } \\
\text { preference \& sales. }\end{array}$ & 4.04 & 0.790 & A \\
$\begin{array}{l}\text { Loyalty programs, discounts, displays provide incentives that encourage product } \\
\text { purchase. }\end{array}$ & 4.210 .640 & A \\
The strategy influences $\quad$ consumer perceptions \& product preferences. & 4.05 & 0.657 & A \\
Increased customer interest results in greater attention to store brands. & 4.08 & 0.706 & A \\
Strategy guides buying decisions that stimulate purchase & 4.12 & 0.742 & A \\
\hline Composite Mean & $\mathbf{4 . 1 0}$ & $\mathbf{0 . 7 0 7}$ & $\mathbf{A}$ \\
\hline
\end{tabular}


As shown in Table 1, respondents agree on the overall customers' promotional strategies' preference on the aspect of sales promotion, with a composite mean of 4.10 and a standard deviation of 0.707 , showing little volatility in the responses. Respondents agree on the sales promotion tools used by Western Appliances in terms of samples, shopping cards \& coupons that build brand preference \& sales (WAM=4.04), incentive provided to customers by loyalty programs and displays that encourage product purchase (WAM=4.21), the influence of sales promotion strategies for consumer perceptions and product preferences (WAM=4.05), sales promotion strategies resulting in increased customer interest (WAM=4.08) and sales promotion strategy that guides buying decisions stimulates purchase (WAM=4.12). The average standard deviation of 0.707 describes the homogeneity of the respondents on this issue, showing small dispersion of data points from the mean that accuracy of the mean value for the sample.

The strategies aimed at increased sales in the short run are perceived to be effective, offering better value to customers causing immediate responses of buyers for purchase decisions and actual product purchase. According to Daramola, Okafor and Bello (2014), this is brought by aggressive sales promotion, hence, organizations must be aware of the most appropriate sales promotional strategy needed to achieve marketing objectives. It is congruent with Familmaleki et al. (2015) that there is direct impact of sales promotion on customers' buying decisions and behavior. Inducing promotional strategies of price discounts, free samples and social surroundings motivate customer's purchasing behaviors and behavioral intentions. Attractive strategies of sales promotion also enhance repurchase intentions and customer satisfaction.

As shown in the table 2, respondents showed preference on advertising strategies which demonstrated effectiveness and ease of product use (WAM=4.09) and the use of web technologies and tools used to build visit frequency and store traffic (WAM=3.89), advertising strategies are perceived to result in cost effectiveness for business development $(\mathrm{WAM}=4.05)$. Their perceptions also show agreement that customer learning changes behavior towards product purchase $(\mathrm{WAM}=4.11)$ and brand comparison and purchase evaluation are possible through advertising strategies of publications and campaigns (WAM=4.15). All these statements are rated "Agree." 


\section{Table 2}

\section{Customers' Perception on Advertising Strategies}

\begin{tabular}{lcccc}
\hline \multicolumn{1}{c}{ Advertising Indicators } & M & S.D. & V.I. \\
\hline Advertising demonstrates effectiveness \& ease of product use. & 4.09 & 0.683 & A \\
$\begin{array}{l}\text { Web technology \& advertising tools build visit frequency \& create store } \\
\text { traffic. }\end{array}$ & 3.89 & 0.723 & A \\
$\begin{array}{l}\text { Results in cost effective methods for business development. } \\
\text { Achieves customer learning that changes behavior towards product purchase. }\end{array}$ & 4.11 & 0.777 & A \\
$\begin{array}{l}\text { Publications \& campaigns allow customer to compare brands \& evaluate } \\
\text { purchase possibilities. }\end{array}$ & 4.15 & 0.729 & A \\
\hline \multicolumn{1}{c}{ Composite Mean } & & & \\
\hline
\end{tabular}

The average standard deviation of 0.737 describes the homogeneity of the responses regarding advertising preferences of customers that can lead to buying decisions and actual purchase of the respondents' product offerings. The low standard deviation shows small dispersion of data points from the mean indicating accuracy of the mean value for the sample. The advertising strategies inform them of the existence of the products and the availability of all information necessary in making evaluations that ascertain product performance which meets customer level of product expectations. It is consistent with that of Furaji et al. (2013) that advertising directly influences behaviors and attitudes of customers. It is used by firms as a major tool to increase awareness on products in customer's mind essential in making decisions to purchase.

As presented in Table 3, respondents' promotional preferences on personal selling strategies show agreement that selling skills and capabilities of salespeople enhance their buying behavior (WAM=4.23; $\mathrm{SD}=0.566$ ) and the strategy customizes sales message to customers that provide assistance in buying behavior (WAM=4.11; SD=0.601). They also agree that salesperson's behavior influences customer's purchase interest (WAM=4.10) and their competencies attract customer behavior leading to purchase (WAM=4.13). Agreement on customer's perceptions of salesman's sincerity \& behavior enhance buying decisions is revealed by the mean value of 4.19 and standard deviation of 0.631 . The overall mean of 4.5 indicates respondents' agreement on their promotional preference of personal selling that result in buying intentions of customers on the product offerings of the respondent firm. 
Judging from the low overall standard deviation score of 0.658 , shows homogeneity of respondents' responses.

\section{Table 3}

Customers' Perception on Personal Selling Strategies

\begin{tabular}{|c|c|c|c|}
\hline Personal Selling Indicators & $\mathbf{M}$ & S.D. & V.I. \\
\hline $\begin{array}{l}\text { Selling skills \& capabilities of salespeople enhance buying } \\
\text { decisions. }\end{array}$ & 4.23 & 0.566 & A \\
\hline $\begin{array}{l}\text { The strategy customizes sales message to customers that provide } \\
\text { assistance in buying behavior. }\end{array}$ & 4.11 & 0.601 & A \\
\hline Salesperson's behavior influences customer's purchase interest. & 4.10 & 0.745 & A \\
\hline $\begin{array}{l}\text { Competencies of salespeople attract customer behavior that lead to } \\
\text { purchase. }\end{array}$ & 4.13 & 0.748 & A \\
\hline $\begin{array}{l}\text { Customer's perceptions of salesman's sincerity \& behavior enhance } \\
\text { buying decisions. }\end{array}$ & 4.19 & 0.631 & A \\
\hline Composite Mean & 4.50 & 0.658 & $\mathbf{A}$ \\
\hline
\end{tabular}

These findings imply that personal selling strategies of the respondent firms are carried out effectively by the salespeople, through the offering of precise products and services to their customers. According to Anyadighibe et al. (2014), the promotional strategy of personal selling enhances customer retention, customer relationship, and increases the firm's sale's volume.

Table 4 presents the perceptions of respondents on preferences for direct marketing strategies implemented by the company. The table shows agreement of respondents that direct marketing strategies communicates directly to customers through catalogues, letters, newspapers, magazines to get direct response of product preferences, campaigns achieve direct response from relevant target customers, email marketing delivers messages \& accurately measures buying behavior, online channels \& social media communicate directly to create contents that generate responses on buying decisions \& purchases, media employed guides buying decisions \& generates customer purchases indicated by the mean values of $4.11,4.02,3.97,3.95, \& 3.87$, respectively. Homogeneity of responses are supported by the 
standard deviations of $0.634,0.791,0.731,0.701$, and 0.812 , for sales promotion, advertising, personal selling, direct marketing, and public relations, respectively.

\section{Table 4}

Customers' Perception on Direct Marketing Strategies

\begin{tabular}{|c|c|c|c|}
\hline Direct Marketing Indicators & $\mathbf{M}$ & S.D. & V.I. \\
\hline $\begin{array}{l}\text { Communicates directly to customers through catalogues, letters, } \\
\text { newspapers, magazines to get direct response of product preferences. }\end{array}$ & 4.11 & 0.634 & A \\
\hline Campaigns achieve direct response from relevant target customers. & 4.02 & 0.791 & A \\
\hline $\begin{array}{l}\text { Email marketing delivers messages \& accurately measures buying } \\
\text { behavior. }\end{array}$ & 3.97 & 0.731 & A \\
\hline $\begin{array}{l}\text { Online channels \& social media communicate directly to create contents } \\
\text { that generate responses on buying decisions \& purchases. }\end{array}$ & 3.95 & 0.701 & A \\
\hline $\begin{array}{l}\text { Media employed guides buying decisions \& generates customer } \\
\text { purchases. }\end{array}$ & 3.87 & 0.812 & A \\
\hline Composite Mean & 3.98 & 0.735 & $\mathbf{A}$ \\
\hline
\end{tabular}

As indicated by the composite mean of 3.98 , and standard deviation of 0.735 , this finding shows customers perceptions of their preference for the promotion tool that direct marketing strategy adopted by the subject retail firm is providing customers products and services benefits suitable to satisfy their specific needs. As customers have less time and energy to explore in the market, direct marketing strategy provides them with all necessary information that aid them in their decisions for buying. As mentioned by Tushar (2014) that there is positive effect of direct marketing on consumer buying decisions.

Perceptions of respondents on promotional preferences for public relations strategies are shown in Table 5. Findings show agreement of the respondents on the promotional preferences for public relations on good image established by public relations stimulates buying decisions, awareness \& preference for firm's products are improved by establishing good community relations, strategies generate goodwill \& create positive buyer behavior, favorable publicity press releases $\&$ consumer surveys influence buying decisions, and news worthy information attract attention of customers, with mean values of 4.13, 4.07, 4.11, 4.00, 4.08 , respectively. 


\section{Table 5}

Customers' Perception on Public Relations Strategies

\begin{tabular}{|c|c|c|c|}
\hline Public Relations Indicators & $\mathbf{M}$ & S.D. & V.I. \\
\hline $\begin{array}{l}\text { Good image established by public relations stimulates buying } \\
\text { decisions. }\end{array}$ & 4.13 & 0.646 & A \\
\hline $\begin{array}{l}\text { Awareness \& preference for firm's products are improved by } \\
\text { establishing good community relations }\end{array}$ & 4.07 & 0.671 & A \\
\hline Strategies generate goodwill \& create positive buyer behavior. & 4.11 & 0.567 & A \\
\hline $\begin{array}{l}\text { Favorable publicity press releases \& consumer surveys influence } \\
\text { buying decisions. }\end{array}$ & 4.00 & 0.804 & A \\
\hline News worthy information attract attention of customers. & 4.08 & 0.812 & A \\
\hline Composite Mean & 4.08 & 0.699 & $\mathbf{A}$ \\
\hline
\end{tabular}

The composite mean of 4.08 shows agreement of the promotional preferences of customers on the overall strategy of public relations, illustrating some degree of homogeneity of responses, shown by the average standard deviation of 0.699. This finding implies preference of customers on public relations strategy of the subject firm for maintaining customer relations intended for customer purchase decisions and complete mutual communication with buyers. This strategy builds on the principles of social responsibility and improvement its organizational image in the community. Public relations activities include the provision of support and positive participation in environmental, social, public and health issues. According to the handbook of Williams (2005), firms recognize public relations' value as a strategic marketing tool aimed at increasing sales of products and services. It can be utilized alone or as part of an integrated campaign for marketing where the strategy of public relations contributes to increased sales in varied ways.

As presented in Table 6, respondents agree on the capability of sales promotion strategy to induce customer behavior to buy and test the product; coupons, samples, product discounts, and premiums influence customers to buy; price discounts induces brand switching and sale of product earlier than planned; short term incentive tools stimulate product and increase buying quantities; sales promotion creates value for money that results in immediate product purchase, indicated by the mean values of 4.08, 4.26, 4.08, 4.00, and 4.03. Homogeneity of responses on their agreement of sales promotion strategy leading to 
buying decisions are shown by the small standard deviation values for all sales promotion indicators.

Table 6

Buying Decisions of Respondents Based on Sales Promotion Strategies

\begin{tabular}{lcccc}
\hline \multicolumn{1}{c}{ Indicators } & M & S.D. & V.I. \\
\hline Induces customer behavior to buy and test the product. & 4.08 & 0.598 & A \\
$\begin{array}{l}\text { Coupons, samples, product discounts, \& premiums influence customer to } \\
\text { buy. }\end{array}$ & 4.26 & 0.645 & A \\
$\begin{array}{l}\text { Price discounts induce brand switching \& sale of product earlier than } \\
\text { planned. }\end{array}$ & 4.08 & 0.631 & A \\
$\begin{array}{l}\text { Short term incentive tools stimulate product purchase \& increase } \\
\text { buying quantities. }\end{array}$ & 4.00 & 0.682 & A \\
Creates value for money that results in immediate purchase of product. & 4.03 & 0.745 & A \\
\hline \multicolumn{1}{c}{ Composite Mean } & $\mathbf{4 . 0 9}$ & $\mathbf{0 . 6 3 9}$ & $\mathbf{A}$ \\
\hline
\end{tabular}

The composite mean of 4.09 presents agreement of the respondents on the influence of sales promotion on the buying decision for Western Appliances products, supported by the small variation on responses, indicated by the standard deviation of 0.639 . This finding is supported by the study of Paramola et al. (2014), which considers sales promotion strategy as the most prominent promotional tool that leads to good perceptions of the public and ensures product loyalty. When sales promotion strategies are aligned with the needs of target customers, positive reaction and customer attraction can be evoked.

Buying decisions of respondents based on advertising strategies are presented in Table 7. Respondents are in agreement that their buying decisions is due to the effectiveness of the promotional strategies of advertising adopted by Western Appliances. Purchase is made because of product awareness created from advertisements, product selection \& purchase are made possible by excessive print $\&$ electronic media, advertising stimulates preferences of product over similar competing brands, celebrity attachment \& involvement lead to buying decisions \& purchases, and access to product information \& touching appeal of advertised product enhance buying intentions, with mean values of 3.98, 3.95, 3.94, 3.90, and 4.08 , respectively. 


\section{Table 7}

\section{Buying Decisions of Respondents Based on Advertising Strategies}

\begin{tabular}{lcccc}
\hline \multicolumn{1}{c}{ Indicators } & M & S.D. & V.I. \\
\hline $\begin{array}{l}\text { Purchase is made because of product awareness created from } \\
\text { advertisements. }\end{array}$ & 3.98 & 0.619 & A \\
$\begin{array}{l}\text { Product selection \& purchase are made possible by excessive print \& } \\
\text { electronic media. }\end{array}$ & 3.95 & 0.687 & A \\
$\begin{array}{l}\text { Advertising stimulates preferences of product over similar competing } \\
\text { brands. }\end{array}$ & 3.94 & 0.722 & A \\
$\begin{array}{l}\text { Celebrity attachment \& involvement lead to buying decisions \& } \\
\text { purchases. }\end{array}$ & 3.90 & 0.732 & A \\
$\begin{array}{l}\text { Access to product information \& touching appeal of advertised product } \\
\text { enhance buying intentions. }\end{array}$ & 4.08 & 0.661 & A \\
\hline Composite Mean & $\mathbf{3 . 9 7}$ & $\mathbf{0 . 6 8 4}$ & $\mathbf{A}$ \\
\hline
\end{tabular}

Responses are homogeneous indicated by the low standard deviation values. The composite mean of 3.97 show the belief of respondents on the effectiveness of the advertising strategy that result in their buying decisions on the products of Western Appliance, with a low overall standard deviation of 0.864 , indicating homogeneity of responses. These findings imply buying decisions of customers being influenced by their preference for the advertising strategy of the subject organization. With customers' buying decisions, enhanced by the strategy of advertising, the firm's product image have resulted into enhanced buying decisions of customers. According to Bonney (2014), customers obtain information on the products and services being sold by the firm through advertisement. Customers use careful decisions to buy based on reasons that are important to them.

Perceptions on the buying decisions of customers based on their preference for personal selling strategy are presented in Table 8. Respondent agree that purchase decisions are influenced by qualities \& strengths of seller(WAM=4.11), qualities of sales have impact on customers' interest from the store (WAM=4.13), the use of salespeople considers buyer's intentions about product decisions and purchase (WAM=4.04), salesperson perceives and manages customers' emotions about product decisions and purchase (WAM=4.12), and the strategy puts emphasis and importance to customer relationship that enhances product sales (WAM=4.17). 


\section{Table 8}

\section{Buying Decisions of Respondents Based on Personal Selling Strategies}

\begin{tabular}{|c|c|c|c|}
\hline Indicators & $\mathbf{M}$ & S.D. & V.I. \\
\hline Purchase decisions are influenced by qualities \& strengths of seller. & 4.11 & 0.567 & A \\
\hline Qualities of sales have impact on customers' interest from the store. & 4.13 & 0.677 & A \\
\hline $\begin{array}{l}\text { Use of salespeople considers buyer's intentions about product decisions \& } \\
\text { purchase. }\end{array}$ & 4.04 & 0.650 & A \\
\hline $\begin{array}{l}\text { Salesperson perceives \& manages customers' emotions about product } \\
\text { decisions \& purchase. } \\
\text { Strategy puts emphasis \& importance to customer relationship that } \\
\text { enhances product sales. }\end{array}$ & 4.12 & 0.556 & A \\
\hline Composite Mean & 4.11 & 0.607 & $\mathbf{A}$ \\
\hline
\end{tabular}

Overall, perceptions show agreement of the respondents on their buying decisions which are based on the promotional strategy of personal selling, revealed by the mean value of 4.11. Gauging from the average standard deviation of 0.607 , it is clear that opinions of buying decisions of customers exhibit some degree of homogeneity which imply that customers' buying decisions are the result of their preferences for the promotional strategy of personal selling adopted by the respondent organization. The study of Yousif (2016) states that in personal selling, sales arise when salespersons make a connection between the customer and the organization. Salespeople contribute to the creation of good image and excellent mental impression for the firm among its customers.

As shown in Table 9, respondents are in agreement to the buying decisions caused by the promotional strategy of direct marketing adopted by Western Appliances. Respondents agree, with a mean of 3.84, and that customers buying decisions are guided by email marketing, buying response are enhanced through digital technology \& tools, with a mean of 3.94. They also agree on the display ads in web services achieve direct responses for product purchases, social media communication facilitates product purchases, and smartphone-based applications send direct communication that generate customer buying decisions, indicated by the mean values of 3.88, 3.93, and 3.88, respectively. Responses are homogeneous shown by the low standard deviations for all direct marketing indicators. 


\section{Table 9}

\section{Buying Decisions of Respondents Based on Direct Marketing Strategies}

\begin{tabular}{lccc}
\hline \multicolumn{1}{c}{ Indicators } & M & S.D. & V.I. \\
\hline Customers buying decisions are guided by email marketing. & 3.84 & 0.662 & A \\
$\begin{array}{l}\text { Buying response are enhanced through digital technology \& tools. } \\
\begin{array}{l}\text { Display ads in web services achieve direct responses for product } \\
\text { purchases. }\end{array}\end{array}$ & 3.94 & 0.763 & A \\
Social media communication facilitates product purchases. & 3.88 & 0.686 & A \\
$\begin{array}{l}\text { Smartphone-based applications send direct communication that } \\
\text { generate customer buying decisions. }\end{array}$ & 3.88 & 0.742 & A \\
\hline \multicolumn{1}{c}{ Composite mean } & $\mathbf{3 . 8 9}$ & $\mathbf{0 . 7 1 7}$ & $\mathbf{A}$ \\
\hline
\end{tabular}

The composite mean of 3.89 perceives that buying decisions of respondents are influenced by the effectiveness of the chosen promotional strategy of direct marketing. The above findings point out the effectiveness of the adopted direct marketing strategy that induce buying decisions of the customers over the range of products of Western Appliances. The average standard deviation of perceptions equivalent to 0.717 show that responses on the buying decisions of customers reveal some degree of homogeneity.

Customers perceive that the strategy extends the benefits of direct marketing engagement with the firm in a variety of ways. Mahon (2017) considers direct marketing as highly effective method of recognizing brands which can result in higher return on investment. The strategy provides ease of buying to customers and quick response to their needs and demand for accurate information.

The findings shown in Table 10 reveal the perceptions of the respondents on buying decisions influenced by the promotional strategy of public relations. Respondents agree that buying preferences for the firm's products are made possible by product publicity (WAM=3.91), good community relations result in increased customer preference for company products $(\mathrm{WAM}=4.13)$, news releases on firm's website enhance product sales (WAM=4.0), public relations strategies deliver consistent customer messages that encourage product purchase $(\mathrm{WAM}=4.09)$, and public services strategies create company identity that attracts potential customers (WAM=4.14). The overall mean of 4.05 shows agreement on the 
buying decisions of customers based on their preference for public relations strategy adopted by Western Appliances. The average standard deviation of 0.627 suggests homogeneity of responses.

\section{Table 10}

Buying Decisions of Respondents Based on Public Relations Strategies

\begin{tabular}{lrrrr}
\multicolumn{1}{c}{ Indicators } & M & S.D. & V.I. \\
\hline $\begin{array}{l}\text { Buying preferences for the firm's products are made possible by } \\
\text { product publicity. }\end{array}$ & 3.91 & 0.588 & A \\
$\begin{array}{l}\text { Good community relations result in increased customer preference for } \\
\text { company products. }\end{array}$ & 4.13 & 0.678 & A \\
$\begin{array}{l}\text { News releases on firm's website enhance product sales. } \\
\text { Public relations strategies deliver consistent customer messages that }\end{array}$ & 4.00 & 0.569 & A \\
$\begin{array}{l}\text { encourage product purchase } \\
\text { Public services strategies create company identity that attracts }\end{array}$ & 4.14 & 0.683 & A \\
potential customers. & & & & \\
\hline Composite Mean & $\mathbf{4 . 0 5}$ & $\mathbf{0 . 6 2 7}$ & A \\
\hline
\end{tabular}

This finding implies awareness of the respondents on the involvement of Western Appliances in promotional activities that can be measured in the areas of social activities, charity, customer loyalty support, acceptance of complaints and criticisms, and addressing issues and problems on health and environment. This is in relation to the study of Familmaleki (2015). Public relations strategy has the capacity in closing the gap between how the public views the firm and the way the company would like to be seen by its public.

Table 11 presents the significant relationship between promotional strategies implemented by the respondent firm and buying intentions of customers. As shown in the table, promotional strategies implemented by the subject firm have significantly high positive correlations with all the preferences variables, indicated by the Pearson Correlation values of 0.586 for sales promotion, 0.629 for advertising, 0.536 for personal selling, 0.693 for direct marketing, 0.666 for public relations. $\rho$ value for all variables is 0.000 with correlation significant at 0.01 level (2-tailed), the null hypothesis is rejected. There are significant high positive correlations between all the promotional strategies variables and customers' buying 
decision variables. These findings imply that a change in the level of effectiveness of the implementation of the promotional strategies' variables will influence the level of customers' buying decisions in a positive linear direction. An increase in the level of effectiveness of the implementation of the promotional strategies will result in an increase in customers' buying intentions and product purchases.

\section{Table 11}

Test of Relationship between the Promotional Preferences and the Promotional Strategies

\begin{tabular}{|c|c|c|c|c|c|c|c|c|}
\hline $\begin{array}{c}\text { Promotional } \\
\text { Preferences of } \\
\text { Buyers }\end{array}$ & $\mathbf{N}$ & $\mathbf{M}$ & S.D. & $\begin{array}{c}\text { Sum of } \\
\text { Squares \& } \\
\text { Cross- } \\
\text { products }\end{array}$ & Covariance & $\begin{array}{l}\text { Sig }(2- \\
\text { tailed) }\end{array}$ & $\begin{array}{c}\text { Pearson } \\
\text { Correlation }\end{array}$ & Interpretation \\
\hline Sales Promotion & 100 & 4.1 & 0.494 & 11.61 & 0.117 & .000 & $.586^{* *}$ & $\begin{array}{l}\text { High Positive } \\
\text { Correlation }\end{array}$ \\
\hline Advertising & 100 & 4.06 & 0.504 & 12.71 & 0.128 & .000 & $.629 * *$ & $\begin{array}{c}\text { High Positive } \\
\text { Correlation }\end{array}$ \\
\hline Personal Selling & 100 & 4.16 & 0.492 & 10.57 & 0.107 & .000 & $.536 * *$ & $\begin{array}{c}\text { High Positive } \\
\text { Correlation }\end{array}$ \\
\hline Direct Marketing & 100 & 3.98 & 0.535 & 14.86 & 0.15 & .000 & $.693 * *$ & $\begin{array}{l}\text { High Positive } \\
\text { Correlation }\end{array}$ \\
\hline Public Relations & 100 & 4.07 & 0.517 & 13.8 & 0.139 & .000 & $.666 * *$ & $\begin{array}{l}\text { High Positive } \\
\text { Correlation }\end{array}$ \\
\hline
\end{tabular}

**. Correlation is significant at the 0.01 level (2-tailed)

The $\rho$ value of 0.000 , less than $1 \%$ significance level rejects the null hypothesis of no significant relationship between the variables. There are statistically significant correlations between the promotional strategies and customer buying decisions variables. Therefore, increase or decrease in effectiveness of promotional strategies' implementation significantly results in an increase or decrease in the purchase decisions of customers in Western Appliances in Metro Manila.

The sum of squares values reveals the amount of variation present in the dependent variable of purchase decisions and how much data set vary around the mean. The sum of squares values indicates good fit of the data in the correlation model. The covariance values show positive direction of the linear relationship between the two variables, with promotional strategies and buying decisions variables tend to increase or decrease together. This is similar to the tudy of Khanfar (2016) which examined the effect of promotional dimensions of sales 
promotion, advertising, public relations, and personal selling on consumers buying decisions and found significant effects of all the independent variables on customer buying decisions, with sales promotion having the highest effect.

\section{Table 12}

Test of Significant difference in the Preferences of Respondents Promotional Strategies

\begin{tabular}{|c|c|c|c|c|c|c|c|c|c|}
\hline & \multirow{2}{*}{\multicolumn{2}{|c|}{$\begin{array}{l}\text { Equality of } \\
\text { Variances }\end{array}$}} & \multirow{2}{*}{\multicolumn{7}{|c|}{ t-test for Equality of Means }} \\
\hline & & & & & & & & & \\
\hline & \multirow{2}{*}{$\mathbf{F}$} & \multirow{2}{*}{ Sig. } & \multirow{2}{*}{$\mathbf{t}$} & \multirow{2}{*}{ df } & \multirow{2}{*}{$\begin{array}{l}\text { Sig. (2- } \\
\text { tailed) }\end{array}$} & \multirow{2}{*}{$\begin{array}{c}\text { Mean } \\
\text { Difference }\end{array}$} & \multirow{2}{*}{$\begin{array}{l}\text { Std. Error } \\
\text { Difference }\end{array}$} & \multicolumn{2}{|c|}{$\begin{array}{l}95 \% \text { Conf Int. of the } \\
\text { Diff. }\end{array}$} \\
\hline & & & & & & & & Lower & Upper \\
\hline $\begin{array}{l}\text { PPEqual variances } \\
\text { assumed }\end{array}$ & .721 & .398 & .594 & 98 & .554 & .05000 & .08500 & -.11797 & .21881 \\
\hline $\begin{array}{l}\text { Equal variances } \\
\text { not } \\
\text { assumed }\end{array}$ & & & .5949 & 4.201 & .554 & .05042 & .08485 & -.11806 & .21889 \\
\hline
\end{tabular}

Levene's test for equality of variances tests the null hypothesis that promotional strategies preferences of customers of Western Appliances and buying decisions have equal variances. Test statistic of 0.594 (with equal variances assumed) indicates that the two variables have equal variances, and the null hypothesis is true and accepted. There is no significant difference in the promotional preferences of customers of the respondent organization, when grouped according to gender.

Promotional strategies preferences of the customers do not significantly differ, based on gender classification. Table 12 presents the significant difference in the independent and dependent variables. The T-test result, with equal variances not assumed, shows t-statistic of 0.594 with 94.201 degrees of freedom. The corresponding two-tailed $\rho$ value is 0.554 , is higher at both $1 \%$ and $5 \%$ level of significance. The null hypothesis is accepted at both significance levels which means that promotional preferences of male and female customers on the product and service offerings of Western Appliances are just the same.

This finding is supported by the study of Ndubisi (2005), providing evidence on the relationship of promotional preferences, product purchase and repurchase which are general across male and female customers. The preference for promotional strategies of sales promotion, advertising, personal selling, direct marketing, and public relations do not differ based on gender. However, it contradicts Morgan (2017) who noted that various differences exist between male and female in the area of communication. 


\section{Table 13}

\section{Regression Model Summary}

Change Statistics

\begin{tabular}{|c|c|c|c|c|c|c|c|c|c|c|}
\hline Model & $\mathbf{R}$ & R Square & $\begin{array}{l}\text { Adjusted R } \\
\text { Square }\end{array}$ & $\begin{array}{l}\text { Std. Error } \\
\text { of the } \\
\text { Estimate }\end{array}$ & $\begin{array}{c}\text { R Square } \\
\text { Change }\end{array}$ & F Change & df1 & df2 & $\begin{array}{c}\text { Sig. F } \\
\text { Change }\end{array}$ & $\begin{array}{l}\text { Durbin- } \\
\text { Watson }\end{array}$ \\
\hline 1 & $.762^{\mathrm{a}}$ & .581 & .559 & .26905 & .581 & 26.060 & 5 & 94 & .000 & 1.967 \\
\hline
\end{tabular}

a. Predictors: (Constant), PR, SP, PS, DM, AD

b. Dependent Variable: BB

As presented in Table 13, the Regression Model Summary, $\mathrm{R}^{2}$ value of 0.0 .581 measures the proportion of variation in the promotion strategies variable explained by variations in buying decisions' indicators. It captures $58.1 \%$ deviations in the dependent variable explained by the regression model, a measure of the extent to which total variations of promotional strategies' variable is explained by the model. The high value of $\mathrm{R}^{2}$ below 1.0 suggests that the regression model explains well the variations in the human development variables. $\mathrm{R}^{2}$ value of 0.581 less than 0.75 indicates the absence of multi-collinearity.

Standard error of estimate of 0.269 , measuring dispersion of the promotion strategies variables around its mean is very low compared to ten percent of the mean of its predicted value. This value assesses the accuracy or precision of the predictions, approximates $95 \%$ prediction interval, with $95 \%$ of observations fall within \pm 2 standard error of the regression from the fitted line, almost matching the prediction interval.

The Durbin-Watson test statistic was used to detect relationship between values separated from each other through a given time lag in prediction errors from the regression analysis. The value of $\mathrm{d}$ equivalent to 1.967 assumes the absence of first order autocorrelation in the set of data, with Durbin-Watson statistic in between the critical values of 1.5 and 2.5. 
Table 14

Analysis of Variance for Significance of Regression Model

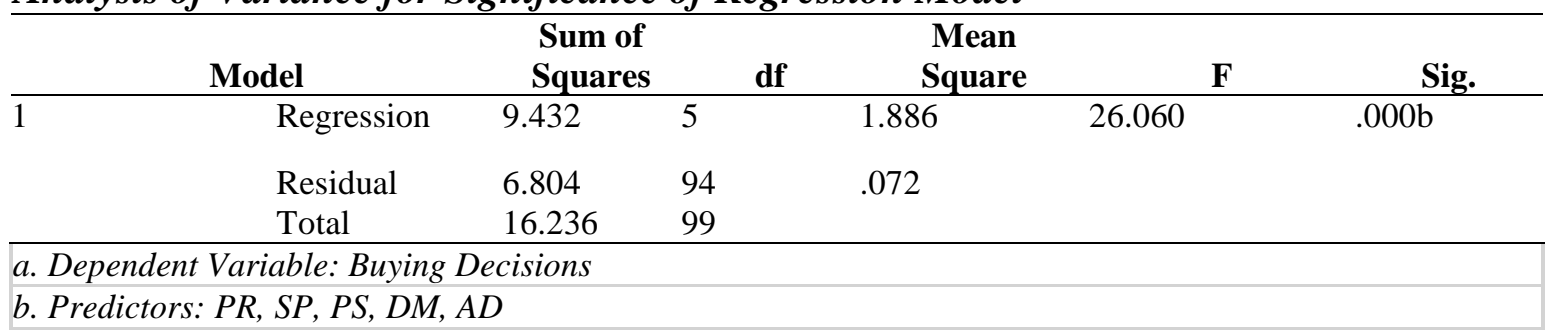

As shown in Table 14, the Analysis of Variance shows the significance of the regression model to explain deviations in the promotion strategies variable and the independent variables of buying decisions statistically and significantly predict the dependent variable of promotion strategies. The value of $\rho$ equivalent to 0.000 less than 0.05 , shows model fit of the regression data, with the model, significant at $95 \%$. Thus, the model is accepted and $\mathrm{R}^{2}$ is significantly different from zero. The F-ratio in the ANOVA test shows fit of the regression model for the data.

The $\mathrm{F}$ value was used to determine statistical significant predictive capability of the model as a whole. F-test value of 20.06 , rejects the null hypothesis of no linear relationship between the variables with the dependent variable and the model has predictive capability where all regression coefficients are not equal to zero. The test is highly significant, with $\mathrm{R}^{2}$ not equal to zero, there is linear relationship between independent variables and the buying decisions variable in the model, with $95 \%$ confidence of the ability of the regression model to explain the dependent variable.

Table 15 presents data on how strongly the independent variables of sales promotion, advertising, personal selling, direct marketing, and public relations predict the dependent variable of customer buying decisions and the reliability of individual beta coefficients. It describes the statistical relationship between each of the predictor promotion strategies variables and the buying decision variable. The $\rho$ values of $0.016,0.036,0.054$, $0.001,0.019$, for sales promotion, advertising, and personal selling variables, direct marketing, and public relations, respectively, at 0.05 significance level, reveal that these variables are predictors of customer buying decisions. The null hypotheses of the five variables are rejected. The low $\rho$ values provide the strong evidence of the rejection of the null hypotheses. These findings imply that changes in the effectiveness of the implementation of the promotion strategies will affect customer buying decisions. The variables are 
statistically significant. Changes in the predictor variables of sales promotion, advertising, and personal selling, direct marketing are associated in buying decisions of customers. This finding further implies that changes in the level of promotion strategies variables will influence the level of customer buying decisions.

Table 15

Regression Coefficients of Promotion

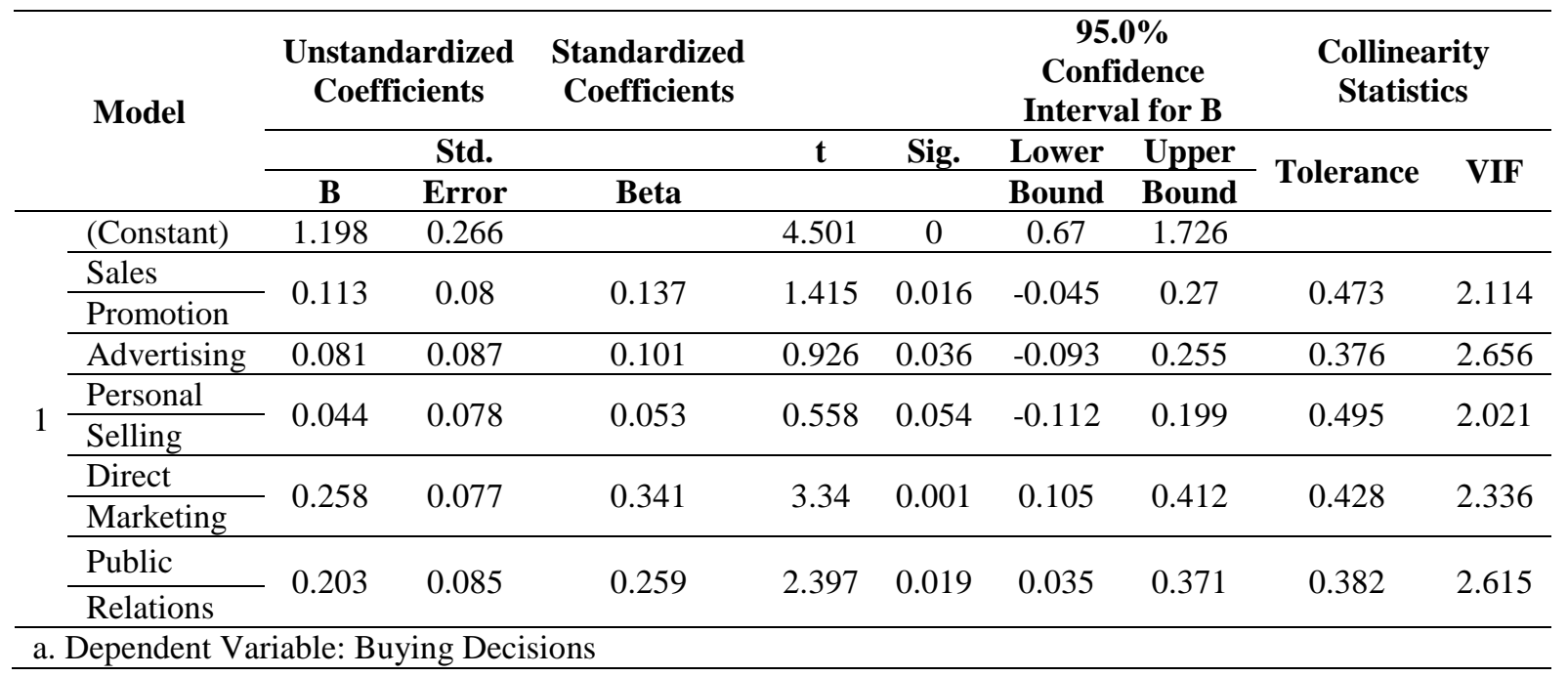

Results of the analysis is supported by the study of Mughal et al. (2014) which provides evidence of the positive attitude of customers towards preferences of the promotional tools that result in buying decisions and behavior. The buying behavior of consumers are motivated by various kinds of promotional techniques which can include sales promotion, advertising, personal selling, public relations, and direct marketing.

Unstandardized coefficients presented in Table 15 reveal the degree of how the dependent variable vary with one component of the promotional strategies variable when all other indicators are held constant. The coefficients not equivalent to zero proves the statistical significance of the independent variables of promotion strategies. The $\rho$ values further show that the testing of the null hypotheses for the independent variables result in coefficients statistically significantly different to 0. Predictors' values are related to changes in the response variable. The upper and lower values provide the $95 \%$ confidence limits for the beta estimates and accepted within this degree of confidence. 
Values for Variance Inflation Factor (VIF) shows how much variances are inflated by multi-collinearity which occurs when independent variables are not independent from each other. Due to collinearity that can exist in the regressor promotion strategies variables, the variance inflation factors were used to measure the inflation in the variances of the parameter estimates. The VIF values of $2.114,2.656,2.021,2.336$, and 2.615, for sales promotion, advertising, personal selling, direct marketing, and public relations, respectively, less than 10 , indicates the absence of potential significant multi-collinearity between the independent variables of promotion strategies. Regression of the five promotion strategies has $\mathrm{R}^{2}$ values less than $90 \%$.

Tolerance is a collinearity diagnostic factor determined in the study to identify multicollinearity in the explanatory variables. The small values of $0.473,0.376,0.495,0.428$, 0.382, for sales promotion, advertising, personal selling, direct marketing, and public relations, respectively, greater than 0.1 , suggest significance and the absence of multicollinearity.

\section{Conclusion}

Based on the findings derived from the study, respondents agree on the customers' promotional preference for sales promotion, advertising, personal selling, direct marketing, and public relations which are perceived to influence their buying decisions. Perceptions of respondents show that their buying decisions towards Western Appliances' products and services are due to their preferences for sales promotion, advertising, personal selling, direct marketing, and public relations. There are significant high positive correlations between all the promotional strategies variables and customers' buying decision variables which imply that a change in the level of effectiveness of the implementation of the promotional strategies' variables will influence the level of customers' buying decisions in a positive linear direction. There is no significant difference in the promotional preferences of customers when grouped according to gender. Promotional strategies of sales promotion, advertising, personal selling, direct marketing, and public relations variables are predictors of customer buying decisions. Effectiveness of the promotional strategies in increasing the buying decisions of customers provides a framework for the adoption of the promotional strategies for the firm's competitiveness. 
It is recommended to implement strategies to enhance the promotional strategies in order to continuously induce the buying decisions of existing and potential customers. The company is expected to regularly monitor the implementation of the promotional strategies which influence buying decisions as they have been found to be positively and significantly correlated. The continuous update of the promotional strategies would be a significant predictor of buying decisions. Further studies focused on the other variables not included in the study, which are likely to influence buying decisions of customers are highly encouraged.

\section{References}

Anyadghibe, J., Awara, N., Esu, B. (2014). "The Impact of Personal Selling on the Productivity of Selected Banks in Calabar Metropolis", International Journal of Development and Sustainability, Vol. 3, No. 5, pp. 1697-1708

Ahmad, S.A. (2015). "Impact of Sales Promotion on Consumer Buying Behavior in Pakistan”, International Interdisciplinary Journal of Scholarly Research, Vol. 1, No. 3, p. 14

Black, K. (2010). "Business Statistics Contemporary Decision Making", $6^{\text {th }}$ Edition, John Wiley \& Sons.

Booney, E. (2014). “The Impact of Advertising on Consumer Purchase Decision”, Academia, www.academia.edu.

Calderon, Jose F. \& Gonzales, Expectacion, C. (1993). Methods of Research and Thesis Writing. P. 82, National Bookstore, Inc.

Daramola, G.C., Okafor, L.I., Bello, N.A. (2014). "Sales Promotion on Consumer Purchasing Behavior", International Journal of Business and Marketing Management, Vol. 2, Issue: 1 , pp. 8-13

Dennis Rutzou Public Relations (2017). "Consumer PR- Public Relations to Build Your Brand", Dennis Rutzou Public Relations Pfy Ltd.

Familmaleki, M., Aghighi, A., Hamidi, K. (2015). "Promotion on Customer Purchasing Behavior", International Journal of Economics and Management Science, Vol. 4, Issue: 4 , pp. 2-6

Furaji, F., Latuszynska, M., Wawrzyniak, A., Wasikowska, B. (2013). "Study on the Influence of Advertising Attractiveness on the Purchase Decision of Women and 
Men”, Journal of International Studies, Vol. 6, Issue: 2, pp. 2.-32, DOI: 10$14254 / 2071-8330.2013 / 6-2 / 2$.

Khanfar, I. (2016). "The Effect of Promotion Mix Elements on Consumers Buying Decisions of Mobile Service: The Case of Umniah Telecommuniation Company at Zarga CityJordan, European Journal of Business and Management, Vol. 8, No. 5, pp. 94-100

Keiss, Harold O. (1989). Statistical Concepts for Behavioral Sciences, Allyn \& Bacon, U.S.A., pp. 157-190

Mahon, D. (2017). “Direct Marketing Influences Consumer Buying Decisions”, prweb, pp. 1-60, Mahon Enterprises, Ltd.

MarketingSherpa (2016). "Marketing Research Chart: How Consumers Prefer to Receive Updates \& Promotions from Brands", Inbound Marketing for B2B, 2000-2017

Mughal, A., Mahmood, A., Mohi-ud-deen, A., Ahmad, B. (2014). "The Impact of Promotional Tools on Consumer Buying Behavior: A Study from Pakistan”, Journal of Public Administration and Governance, Vol. 4, No. 3, pp. 402-414. Doi: 10.5296/jpag.v4i36680, http://dx.org/10.5296/jpag.v4i3.6680

Ndubisi, N.O. (2005). "Gender Difference in Customer Behavioral Responses to Sales Promotion", Asia Pacific Management Review", Vol. 10, Issue:3, pp. 175-185

Paramola, G, Okafar, L., Bello, M. Li, M. (2014). "Sales Promotion on Consumer Purchasing Behavior", International Journal of Business and Marketing Management:, Vol. 2, Issue:1,pp. 8-13

Shamout, M.D., (2016). "The Impact of Promotional Tools on Consumer Buying Behavior in Retail Market”, International Journal of Business and Social Science, Vol. 7, No, 1, pp. $75-85$

Tushar, A. (2014). "Communication Mix on Consumer Buying Behavior and Decision in Retail Industry of UK: A Case Study of Tesco PLC”. Prime Research and Consultancy, p. 10 .

Yousif, R. (2016). "The Impact of Personal Selling on the Purchasing Behavior Towards Clothes: A Case Study on the Youth Category", International Journal of Marketing Studies", Vol. 8, No. 5, pp, 128-135 